\title{
Finasteride for recurrent priapism in children and adolescents: $A$ report on 5 cases
}

\author{
Ubirajara Barroso Jr., Thamy C.S. Marques, Hugo F.F. Novaes \\ Escola Bahiana de Medicina e Saúde Pública, BA, Brazil
}

\section{ABSTRACT}

Purpose: Recurrent priapism is prevalent in children. Different medications have been used to avoid new episodes, however, there is no consensus regarding the best option. The use of finasteride to treat priapism in adults has already been tested. The aim of the present study was to test the hypothesis that a low dose of finasteride would be effective in preventing recurrent priapism in children.

Materials and Methods: Since 2007, five children and adolescents with recurrent episodes of priapism have been treated with finasteride in our department, and the medical records of these patients were reviewed for this study. In four cases, the dose used was $1 \mathrm{mg}$ a day, while the remaining patient used $1 \mathrm{mg}$ twice a day.

Results: Prior to initiating finasteride treatment, one patient reported having had 6 episodes of acute priapism, while the remaining patients had more than 10 episodes. One of the patients reported having stuttering priapism almost daily. With a mean follow-up of 20 months, four patients had no episodes and only one patient complained of sporadic and shorter duration episodes.

Conclusions: These initial results suggest that a low daily dose of finasteride appears to represent an effective and safe form of treatment for recurrent priapism in children and adolescents with SCD. However, in order to confirm these initial findings, studies with a large population and a control group are essential.

\section{ARTICLE INFO}

\section{Key words:}

Priapism; Child; Anemia,

Sickle Cell; Finasteride

Int Braz J Urol. 2012; 38: 682-6

Submitted for publication:

February 12, 2012

Accepted after revision:

June 26, 2012

\section{INTRODUCTION}

Priapism is defined as an involuntary erection unassociated with sexual arousal that may be painful and persistent. It is considered a medical emergency that may result in erectile dysfunction if not treated promptly. Priapism in children is generally associated with sickle cell disease (SCD) (1-3). The incidence of priapism in children with SCD is estimated to be between $35 \%$ and $89 \%(1,3)$. Approximately $27 \%$ of patients with sickle cell disease between 5 and 20 years of age have at least one episode of priapism and the probability of having at least one episode of priapism by age 20 was reported to be $89 \%$
(4). It is generally presented clinically as a painful, self-limiting event of short duration; however, recurrent episodes of priapism may result in physical and emotional damage in both children and adults (5).

Recurrent priapism is common in children $(2,5)$. Different medications have been used to prevent the occurrence of new episodes; however, there is no consensus on the best option (6). Hydroxyurea is an alternative for the prevention of attacks of severe vaso-occlusive disease, but its benefits for the treatment of priapism are not yet fully established $(7,8)$.

The guidelines of the American urological Association (AUA) cite the use of GnRh ana- 
logues to prevent new episodes of priapism in adults; however, this treatment, aside from being expensive, may lead to a decrease in libido and should be avoided in children (9).

Anti-androgens have been used to treat priapism in adults with satisfactory results $(2,5,6,10)$. The dose of $100 \mathrm{mg} /$ day of cyproterone acetate is associated with a reduction in nocturnal priapism attacks and a 50\% reduction in serum LH, FSH and testosterone levels. On the other hand, patients experience a loss of libido (5). Treatment with bicalutamide (50 mg) was reported in three young men with recurrent priapism (10). No new episodes occurred while the patients were on the medication, but one patient developed breast swelling and gynecomastia. No change in libido was reported.

Finasteride has already been evaluated by Rachid-Filho et al. for the prophylactic treatment of priapism in adolescents and adults (6). In that study, 35 patients were treated with decreasing doses of $5 \mathrm{mg}, 3 \mathrm{mg}$ and $1 \mathrm{mg}$ of finasteride daily for 4 months. The age of the patients ranged from 15 to 53 years, and they all had sickle cell disease and a history of recurrent priapism. After treatment, $46 \%$ of the patients reported a cessation of priapism episodes. The authors failed to describe how many patients were under 18 years of age and did not report the outcome for this specific group. The aim of the present study is to test the hypothesis that a low dose of finasteride would be effective in preventing recurrent priapism in children.

\section{MATERIAL AND METHODS}

Since 2007 all children and adolescents with recurrent episodes of priapism have been treated with finasteride in our department. The medical records of these patients were reviewed for this study. In four cases, the dose used was 1 $\mathrm{mg}$ a day, while the remaining patient received 1 mg twice a day.

All patients were contacted and interviewed together with their parents. Data were obtained on the number of episodes of priapism prior to and following the beginning of medication, the maximum and minimum duration of the episodes, whether or not the attacks were painful, whether any surgical procedure had been needed, and erectile function before and after the use of finasteride. Priapism was defined as the presence of a persistent, spontaneous, painful erection. None of the patients had ever had sexual intercourse before treatment. To evaluate erectile function, we asked the mothers of children and adolescents who had not started sexual life on the presence of nocturnal or morning erections. Adolescents who had initiated sexual life during follow-up, reported the presence of erections during sexual activity. Two were prepubescent and 3 were going through puberty.

There was no signing of informed consent, since the data were obtained through chart review and follow-up was obtained by telephone. The decision to use finasteride was made due to the high frequency of episodes of priapism. The study was submitted to the ethics committee of our institution during the course of treatment.

\section{RESULTS}

Five patients with recurrent priapism, all of whom had SCD, were evaluated. Prior to initiating finasteride treatment, one patient reported having had 6 episodes of acute priapism, while the remaining patients had had more than 10 episodes. One of the patients reported having non painful sporadic episodes of shorter duration (stuttering priapism) almost daily. The duration of the episodes ranged from 30 minutes to 17 hours. During the emergency, one patient could only effectively treat his episode through venous hydration. In three patients, both venous hydration and drainage of the corpora cavernosa were necessary. One patient underwent distal spongious cavernosa fistula after failure of a more conservative treatment.

Finasteride was used for a mean of $7.5 \pm$ 3 months (range 6-14 months). The mean age of the patients at beginning of treatment with finasteride was $12.0 \pm 3.08$ years (range 8-16 years). During treatment, two patients had 2 episodes of stuttering priapism and one had eight. These patients were among those who reported more than 10 episodes previously. However, all episodes 
were of short duration and involuted spontaneously. After treatment, four patients had no episodes at all, and one patient reported stuttering priapism. In an attempt to treat the episodes, this last patient used finasteride intermittently without his doctor's consent (self-medication). The mean duration of follow-up was 20 months (range 9-31 months). No side effects were reported. All patients reported normal, full erections (Table-1).

\section{DISCUSSION}

Priapism is a medical emergency that mainly affects patients with SCD. It may result in permanent damage to the patient (11). It is believed that the phenomenon of vaso-occlusion, very common in patients with SCD, may hamper blood circulation to the penis (12). Since there is no standard treatment for the prevention of further attacks, it is very common for children with priapism to have been submitted to several different forms of management $(2,6,13)$.

Priapism often occurs as an episode of short duration. More conservative forms of management have been attempted as a means of treating the attacks. It is very important that patients with SCD who experience episodes of priapism be managed first with hydration, pain and anxiety relief, and alkalinization of the blood; this approach does not resolve the priapism episode, that can be treated with drainage of the corpora cavernosum and possibly the injection of adrenergic agents into the corpora cavernosum. More invasive approaches such as surgery to decompress the corpora cavernosa are restricted to the refractory acute attacks.(11,14). The recurrence of the acute episodes is common. The use of vasodilator agents such as pentoxifylline (12), as well as several anti-androgenic drugs such as flutamide, bicalutamide (10) and cyproterone acetate $(5,10,12)$ have been used to prevent further attacks.

Table 1 - Details of the treatment.

\begin{tabular}{|c|c|c|c|c|c|}
\hline & Patient 1 & Patient 2 & Patient 3 & Patient 4 & Patient 5 \\
\hline Age at first episode & 14 & 4 & 13 & 9 & 13 \\
\hline $\begin{array}{l}\text { Age at the beginning of } \\
\text { treatment }\end{array}$ & 16 & 8 & 13 & 10 & 13 \\
\hline Age at final follow-up & 18 & 9 & 14 & 11 & 14 \\
\hline Treatment duration (months) & 14 & 6 & 12 & 6 & 6 \\
\hline Dosage of Finasteride & Twice a day & Daily & Daily & Daily & Daily \\
\hline Previous surgical treatment & $\begin{array}{c}\text { Drainage of the } \\
\text { corpora } \\
\text { cavernosa }\end{array}$ & No & $\begin{array}{c}\text { Drainage of the } \\
\text { corpora } \\
\text { cavernosa }\end{array}$ & $\begin{array}{c}\text { Drainage of } \\
\text { the corpora } \\
\text { cavernosa and } \\
\text { distal spongious } \\
\text { cavernosa fistula }\end{array}$ & No \\
\hline Episodes before treatment & 36 & $\begin{array}{l}\text { frequently } \\
\text { (nearly } 2 \text { times } \\
\text { per week) }\end{array}$ & 6 & 10 & $\begin{array}{l}\text { Frequently } \\
\text { (almost daily) }\end{array}$ \\
\hline Episodes during treatment & 8 & 3 & 3 & 0 & 0 \\
\hline Episodes after treatment & 0 & Occasional & 0 & 0 & 0 \\
\hline Follow-up (months) & 31 & 24 & 12 & 9 & 21 \\
\hline
\end{tabular}


Some authors recommend managing recurrent priapism in selected cases of adults with the use of selfadministered intracavernosal injections of alphaadrenergic agonists such as metaraminol, etilefrine and epinephrine (15-17); however, this is not practical in the case of children.

Okpala et al. (13) reported a good clinical response with the alpha-adrenergic agonist, etilefrine $(50-100 \mathrm{mg} / \mathrm{d})$, in $13 / 18$ adults with recurrent priapism (72\%), 17 of whom had SCD. Despite these positive findings, however, side effects such as headache, tachycardia and hypertension are of concern. To our knowledge, there is no record of this drug ever being tested on children.

Finasteride is currently considered an alternative prophylactic treatment for recurrent priapism in adults $(6,12,14)$. This drug acts by inhibiting the type 2 isoform of the 5 alpha-reductase enzyme, which is responsible for the conversion of testosterone into dihydrotestosterone predominantely in hair follicles and the prostate (6). However, the exact mechanism through which this drug reduces the frequency of priapism attacks resulting from vaso-occlusive events is unclear. There is no significant androgenic activity in prepubertal children that would justify the use of this drug (18); however, it has been speculated that its effect may be mainly due to its ability to inhibit calcium efflux from smooth muscle cells (4). It is possible that finasteride may reduce the rate of nocturnal spontaneous erections. Finasteride has little effect on the level of serum testosterone and it has no other steroidal, androgenic, estrogenic or progestinic effects (19). Finasteride acts by inhibiting the action of 5-alpha-reductase type 2 and thus inhibiting the conversion of testosterone into DHT. This enzyme occurs most abundantly in hair follicles and prostate tissue. Therefore, the use of a low dose of finasteride might have little effect in the pubertal androgen development and epiphyseal closure. Of concern is the role of DHT during penis development at puberty. We did not find any complaints of stunted growth of the penis in our patients. However, we recommend that this treatment be performed in low doses and for a short period of time.

The dose of finasteride prescribed for priapism in adults ranges from 3 to $10 \mathrm{mg} /$ day. At these doses, side effects such as a reduction in libido, problems with ejaculation and gynecomastia have been described $(6,12)$. However, these side effects were not found with the use of a $1 \mathrm{mg}$ dose. Rachid-Filho et al. (6) treated 35 adults with recurrent priapism using finasteride, starting at a dose of $5 \mathrm{mg}$ and reducing this dose every 40 days, first to $3 \mathrm{mg}$ and then to $1 \mathrm{mg}$. After the fourth month of evaluation, these investigators observed that 16 patients (46\%) reported no recurrence, while another 16 patients (46\%) had 1-15 recurrent episodes. At the beginning of the treatment with finasteride, the mean number of episodes of priapism per patient had been 22.7 compared to 2.1 after 4 months of treatment. These results show that finasteride successfully decreased and controlled the number of recurrent episodes of priapism in that sample.

In view of the physical and emotional sequelae resulting from fibrosis and erectile dysfunction that may occur as a consequence of recurrent priapism in this age group, attempts to avoid new episodes have been carried out. Antiandrogens are generally used in this population for the purpose of treating endocrine disorders and normalizing a state of hyperandrogenism. In these situations, the use of low-dose antiandrogens corrects the state of hyperandrogenism without causing any relevant side effects. No publications were found on the use of antiandrogens in male children without preexisting hormonal disorders. Therefore, we still do not know the long term safety risks and finasteride should be used in selected cases only.

\section{CONCLUSIONS}

To the best of our knowledge, this is the first study to evaluate the use of finasteride in children. No side effects were found at the doses of 1-2 mg a day in children and adolescents after a maximum of 14 months of use. These results suggest that a 1-mg/ day dose of finasteride is effective in preventing the recurrence of priapism in children and adolescents with SCD. Despite the frequency of attacks in all five patients prior to treatment, only one had short attacks of stuttering priapism during or after finasteride treatment.

\section{CONFLICT OF INTEREST}

None declared. 


\section{REFERENCES}

1. Adeyoju AB, Olujohungbe AB, Morris J, Yardumian A, Bareford $D$, Akenova $A$, et al.: Priapism in sickle-cell disease; incidence, risk factors and complications - an international multicentre study. BJU Int. 2002; 90: 898-902.

2. Cançado RD, Langhi Jr. DM, Chiattone CS, Brasil SA, Marret AC, Naoum FA: Uso do dietil-estilbestrol no tratamento do priaspismo em pacientes com doença falciforme - Relato de dois casos e uma a revisão da literatura. Revista Brasileira de Hematologia e Hemoterapia. 2002; 24: 139-43.

3. Virag R, Bachir D, Lee K, Galacteros F: Preventive treatment of priapism in sickle cell disease with oral and self-administered intracavernous injection of etilefrine. Urology. 1996; 47: 77781; discussion 781 .

4. Mantadakis E, Cavender JD, Rogers ZR, Ewalt DH, Buchanan GR: Prevalence of priapism in children and adolescents with sickle cell anemia. J Pediatr Hematol Oncol. 1999; 21: 518-22.

5. Muneer A, Minhas S, Arya M, Ralph DJ: Stuttering priapism--a review of the therapeutic options. Int J Clin Pract. 2008; 62: 1265-70.

6. Rachid-Filho D, Cavalcanti AG, Favorito LA, Costa WS, Sampaio FJ: Treatment of recurrent priapism in sickle cell anemia with finasteride: a new approach. Urology. 2009; 74: 1054-7.

7. Charache S: Experimental therapy of sickle cell disease. Use of hydroxyurea. Am J Pediatr Hematol Oncol. 1994; 16: 62-6.

8. Al Jam'a AH, Al Dabbous IA: Hydroxyurea in the treatment of sickle cell associated priapism. J Urol. 1998; 159: 1642.

9. Montague DK, Jarow J, Broderick GA, Dmochowski RR, Heaton JP, Lue TF, et al.: American Urological Association guideline on the management of priapism. J Urol. 2003;170: 1318-24.
10. Dahm P, Rao DS, Donatucci CF: Antiandrogens in the treatment of priapism. Urology. 2000; 59: 138.

11. Fowler JE Jr, Koshy M, Strub M, Chinn SK: Priapism associated with the sickle cell hemoglobinopathies: prevalence, natural history and sequelae. J Urol. 1991; 145: 65-8.

12. Begliomini H: Priapism due to "S" and "C" Hemoglobinopathy successflully treated with Finasteride. Int Braz J Urol. 2001; 27: 475-7.

13. Okpala I, Westerdale N, Jegede T, Cheung B: Etilefrine for the prevention of priapism in adult sickle cell disease. $\mathrm{Br} \mathrm{J}$ Haematol. 2002; 118: 918-21.

14. Chakrabarty A, Upadhyay J, Dhabuwala CB, Sarnaik S, Perlmutter AD, Connor JP: Priapism associated with sickle cell hemoglobinopathy in children: long-term effects on potency. J Urol. 1996; 155: 1419-23.

15. Ralph DJ, Pescatori ES, Brindley GS, Pryor JP: Intracavernosal phenylephrine for recurrent priapism: self-administration by drug delivery implant. J Urol. 2001; 165: 1632.

16. Steinberg J, Eyre RC: Management of recurrent priapism with epinephrine self-injection and gonadotropin-releasing hormone analogue. J Urol. 1995; 153: 152-3.

17. McDonald M, Santucci RA: Successful management of stuttering priapism using home self-injections of the alpha-agonist metaraminol. Int Braz J Urol. 2004; 30: 121-2.

18. Jesus LE, Dekermacher S: Priapism in children: review of pathophysiology and treatment. J Pediatr (Rio J). 2009; 85: 194-200.

19. Patel JC: Hair loss. Indian J Med Sci. 2000; 54: 106-9.

Correspondence address: Dr. Ubirajara Barroso Júnior Rua Sócrates Guanaes Gomes, 73 / 2004, Cidade Jardim

Salvador, BA, 40296-720, Brazil E-mail: ubarroso@uol.com.br 